\title{
Effect of year-round training on parameters of heart rate variability, central hemodynamics and physical working capacity in short-distance swimmers
}

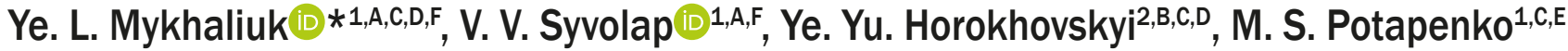 \\ ${ }^{1}$ Zaporizhzhia State Medical University, Ukraine, ${ }^{2}$ Zaporizhzhia National University, Ukraine
}

A - research concept and design; B - collection and/or assembly of data; C - data analysis and interpretation; D - writing the article;

$\mathrm{E}$ - critical revision of the article; $\mathrm{F}$ - final approval of the article

Dynamic examination of athletes is of great interest for sports medicine specialists, as it allows measuring changes in athletes' functional state in parallel with increasing athletic performance in a one-year training cycle.

The aim of the work is to assess dynamic changes in parameters of heart rate variability, central hemodynamics and physical performance in short-distance swimmers during preparatory and competitive periods of the training process.

Materials and methods. The swimmers $(n=94)$ qualified from the second-class sport qualification to Master of Sports of International Class were examined during the preparatory and competitive periods of the training process. Short ECG recordings of 5 minutes were used for the heart rate variability (HRV) analysis according to the International Standard.

Results. In the preparatory period, the autonomic equilibrium index had a mean value of $3.104 \pm 0.4941 / \mathrm{s}^{2}$, and in the competitive period $-2.459 \pm 0.2481 / \mathrm{s}^{2}(P=0.295)$. The initial distribution of athletes depending on the value of autonomic tone, according to the classification proposed by R. M. Bayevskiy, had the following ratio in the preparatory period: $75.0 \% / 20.0 \% / 5.0 \%$, vagotonic, normotonic and sympathotonic individuals, respectively, statistically significantly indicating the prevalence of athletes with vagotonia over normotonic individuals $(P=0.0005)$. In the competitive period, this ratio was $60.0 \% / 40.0 \% / 0 \%$. The central hemodynamic indices showed a downward trend as evidenced by a decrease in the cardiac index from $2.954 \pm 0.126 \mathrm{I} \cdot \mathrm{min}^{-1} \cdot \mathrm{m}^{-2}$ to $2.862 \pm$ $0.0881 \cdot \mathrm{min}^{-1} \cdot \mathrm{m}^{-2}(P=0.510)$, although these values matched to the eukinetic circulatory type (CT) during both training periods. However, the ratio of hypokinetic, eukinetic and hyperkinetic $\mathrm{CT}$ in the preparatory period was $45.0 \%$ / 45.0 \% / $100 \%$, and in competitive period $-45.0 \% / 55.0 \% / 0 \%$, respectively. The mean value of physical working capacity $\left(\mathrm{PWC}_{170 \mathrm{~kg}}\right)$ in the preparatory period was $15.54 \pm$ $0.66 \mathrm{kgm} \cdot \mathrm{min}^{-1} \cdot \mathrm{kg}^{-1}$, and in the competitive period it was $18.09 \pm 0.53 \mathrm{kgm} \cdot \mathrm{min}^{-1} \cdot \mathrm{kg}^{-1}$, making an increase of $16.41 \%(P=0.0001)$. The functional state index (FSI) increased significantly by $25.08 \%$ from $5.558 \pm 0.322$ r. u. to $6.952 \pm 0.272$ r. u. $(P=0.00001)$. The correlation analysis during the preparatory period showed a significant positive correlation between Mo and $P W C_{170 k g}(r=0.46$, $P=0.040), A R I$ and $\mathrm{Cl}(r=0.50, P=0.026)$, IARP and $\mathrm{Cl}(r=0.53, \mathrm{P}=0.017)$, stress-index and $\mathrm{SI}(r=0.52, P \stackrel{170 \mathrm{~kg}}{=} 0.019)$ and negative - between $\mathrm{Mo}$ and $\mathrm{Cl}(\mathrm{r}=-0.56, \mathrm{P}=0.009)$. In the competitive period, the general tendency of correlation interaction was remained, as evidenced by revealed positive relationships between $\mathrm{Mo}$ and FSI $(r=0.53, P=0.017), \mathrm{ARI}$ and $\mathrm{SI}(\mathrm{r}=0.51, \mathrm{P}=0.020)$.

Conclusions. Short-distance swimmers in the competitive period had significantly higher level of physical working capacity (by $16.4 \%$ ), the functional state index (by $25.1 \%$ ), as well as parasympathetic tone of ANS in comparison with the preparatory period. The above-mentioned hemodynamic changes and autonomic balance indicators were associated with the increase in athletic performance: $4(20 \%)$ swimmers qualified for the title of Master of Sports of Ukraine, $2(10 \%)$ swimmers - for Candidate Master of Sports, and 2 (10\%) swimmers - for first-class sport qualification.

\section{Вплив цілорічного тренування на показники варіабельності серцевого ритму, центральної гемодинаміки та фізичної працездатності плавців на короткі дистанції}

\section{Є. А. Михалюк, В. В. Сиволап, Є. Ю. Гороховський, М. С. Потапенко}

Динамічне спостереження за спортсменами викликає чималий науковий інтерес для фрахівців спортивної медицини, оскільки дає змогу констатувати зміни функціонального стану спортсменів паралельно зі зростанням спортивного результату протягом однорічного циклу тренувального процесу.

Мета роботи - оцінити зміни параметрів варіабельності серцевого ритму (ВСР), центральної гемодинаміки та фізичної працездатності плавців на короткі дистанції в підготовчий і змагальний періоди тренувального процесу.

Матеріали та методи. У підготовчому та змагальному періодах тренувального процесу обстежили плавців $(\mathrm{n}=94)$ на короткі дистанції кваліфікації від майстра спорту міжнародного класу до спортсмена 2 розряду. Для аналізу ВСР використали короткі (5-хвилинні) записи ЕКГ відповідно до міжнародного стандарту.

Результати. У підготовчому періоді 75,0 \% плавців мали ознаки ваготонії, 20,0 \% - нормотонії, 5,0 \% - симпатикотонії. Різниця питомої ваги ваготоніків і нормотоніків вірогідна ( $p=0,0005)$. У змагальний період відбувся зсув співвідношення вегетативного балансу в бік нормотонії: 60,0 \% / 40,0 \% / 0 \% відповідно. Поділ плавців за типами кровообігу в підготовчому періоді: гіпокінетичний $-45,0 \%$, еукінетичний $-45,0 \%$, гіперкінетичний $-10,0 \%$; у змагальному періоді $-45,0 \%$, 55,0 \%, 0 \% відповідно. Середнє значення $\mathrm{PWC}_{170 \text { кк }}$ зросло на 16,41 \% (p = 0,0001). Індекс фрункціонального стану збільшився на 25,08 \% ( $p=0,00001)$. Кореляційний аналіз у підготовчий і змагальний періоди показав, що збільшення фізичної працездатності пов'язане зі збільшенням індексу Мо, зменшення індексу Cl - зі зменшенням ВПР і ПАПР і збільшенням Мо, а також зменшення Cl - зі зниженням індексу стресу. Покращилися спортивні результати: 20 \% (n = 4) плавців ви-
Key words: short-distance swimmers, qualification rank from firstclass athletes to master of sports of international class, heart rate variability, central hemodynamics, physical working capacity, periods of the training process.

\section{Zaporozhye} medical journal 2021; 23 (3), 343-347

*E-mail: evg.mikhalyuk@ gmail.com

Ключові слова: плавці на короткі Аистанції, кваліфікаційний ранг віА спортсмена 1 розряау ао майстра спорту міжнародного класу, варіабельність серцевого ритму, центральна гемодинаміка, фізична працезАатність, періоди тренувального процесу.

Запорізький медичний журнал. 2021. T. 23, № 3(126). C. $343-347$ 
конали норматив майстра спорту України, 10 \% (n = 2) спортсменів стали кандидатами в майстри спорту, $10 \%(n=2)$ стали спортсменами 1 розряду.

Висновки. Плавці на короткі дистанції у змагальний період мали на 25,1 \% вищий рівень функціонального стану, на $16,4 \%$ - фізичної працездатності, збільшення тонусу парасимпатичного відділу АНС порівняно з підготовчим періодом. У змагальному періоді збереглися кореляційні зв'язки, що виявлені в підготовчому періоді. Поліпшення спортивних результатів плавців на короткі дистанції асоціювалося з названими змінами показників гемодинаміки та вегетативного балансу.

Ключевые слова: пловцы на короткие Аистанции квалификационный ранг от спортсмена 1 разряна Ао мастера спорта международного класса, вариабельность сердечного ритма, центральная гемодинамика, физическая работоспособность, периоды тренировочного процесса.

Запорожский медицинский журнал. 2021. T. 23, № 3(126). C. $343-347$

\section{Влияние круглогодичной тренировки на показатели вариабельности сердечного ритма, центральной гемодинамики и физической работоспособности пиовцов на короткие дистанции}

\section{Е. А. Михалюк, В. В. Сыволап, Е. Ю. Гороховский, М. С. Потапенко}

Динамическое наблюдение за спортсменами представляет большой интерес для специалистов спортивной медицины, поскольку позволяет констатировать изменения функционального состояния спортсменов параллельно с ростом спортивного результата в течение годичного цикла тренировочного процесса.

Цель работы - оценить изменения параметров вариабельности сердечного ритма (ВСР), центральной гемодинамики и физической работоспособности пловцов на короткие дистанции в подготовительный и соревновательный периоды тренировочного процесса.

Материалы и методы. В подготовительном и соревновательном периодах тренировочного процесса обследовали пловцов ( $n=94$ ) на короткие дистанции квалификации от мастера спорта международного класса до спортсмена 2 разряда. Для анализа ВСР использовали короткие (5-минутные) записи ЭКГ в соответствии с международным стандартом.

Результаты. В подготовительном периоде 75,0% пловцов имели признаки ваготонии, 20,0% - нормотонии, 5,0 \% -симпатикотонии. Разница удельного веса ваготоников и нормотоников достоверна ( $p=0,0005)$. В соревновательный период произошло смещение соотношения вегетативного баланса в сторону нормотонии: 60,0 \% / 40,0 \% / 0 \% соответственно. Распределение пловцов по типам кровообращения в подготовительном периоде: гипокинетический - 45,0\%, эукинетический - 45,0 \%, гиперкинетический - 10,0%; в соревновательном периоде - 45,0 \%, 55,0 \%, 0 \% соответственно. Среднее значение $\mathrm{PWC}_{170 \text { кс }}$ выросло на 16,41 \% ( $\mathrm{p}=$ 0,0001). Индекс фрункционального состояния увеличился на 25,08 \% $(p=0,00001)$. Корреляционный анализ в подготовительный и соревновательный периоды показал, что увеличение физической работоспособности связано с увеличением индекса Мо, уменьшение индекса СИ - с уменьшением ВПР и ПАПР и увеличением Мо, а также уменьшение СИ - со снижением индекса стресса. Улучшились спортивные результаты: $20 \%$ ( $\mathrm{n}=4$ ) пловцов выполнили норматив мастера спорта Украины, 10 \% ( $\mathrm{n}=2$ ) спортсменов стали кандидатами в мастера спорта, $10 \%(n=2)$ стали спортсменами 1 разряда.

Выводы. Пловцы на короткие дистанции в соревновательный период имели на 25,1% выше уровень функционального состояния, на 16,4 - физической работоспособности, увеличение тонуса парасимпатического отдела АНС по сравнению с подготовительным периодом. В соревновательном периоде сохранились корреляционные связи, которые проявлялись в подготовительном периоде. Улучшение спортивных результатов пловцов на короткие дистанции ассоциировалось с указанными изменениями показателей гемодинамики и вегетативного баланса.

Dynamics of the functional state of the athlete's body during the sports season with the most pronounced shifts in the competitive period with their return to standards in the transition period, when the athlete practically does not train, is the most important sports medicine feature [2].

Such dynamic examinations represent a great interest for sports medicine specialists, as it allows measuring changes in the functional state of athletes in parallel with increasing athletic performance in a one-year training cycle [6].

At the same time, there are some difficulties in organizing the process of these examinations, mainly due to a lack of motivation among athletes, being officially allowed to compete, to undergo repeated loading tests on the eve of the responsible start, or if an athlete is in another phase of training session, for the next start preparation. That is why groups of examined athletes are often small, and similar examinations are occasional. In particular, we carried out such studies analyzing brain and central hemodynamic indicators during a one-year training cycle among shot putters including 98 athletes ( 31 women and 67 men) as early as 1989 [5]. Slightly smaller compared groups, for known reasons, were in dynamic studies among sprinters $[8,10]$, and middle-distance 400-meter runners of both sexes [7,9].
Our international colleagues face this kind of challenges. The above assertions appeared to be justified by the fact that Polish researchers were able to compare heart rate variability indicators in pre-competitive and competitive periods in only 11 volleyball players [15], dynamic changes in the physical working capacity among 9 elite handball players [13]. International research of scientists from Brazil, Australia, and Spain combined the results of examinations among 15 futsal players [14]. Comprehensive study on assessing the state of heart rate variability and physical working capacity among 22 handball players throughout the season of play (6 examinations) was conducted by O. N. Kudrya [3]. Thus, in the scientific literature, there are very few studies examining the dynamics of heart rate variability, central hemodynamics and physical working capacity in athletes during preparatory and competitive periods of the training process.

\section{Aim}

To assess dynamic changes in parameters of heart rate variability, central hemodynamics and physical performance in short-distance swimmers during preparatory and competitive periods of the training process. 


\section{Materials and methods}

Swimmers ( $n=94$ ) qualified Master of Sports of International Class, Master of Sports, Candidate Master of Sports, first- and second-class sport qualification were assigned in a group $(n=20)$. Athletes of this group were examined in the competitive period of the training process in addition to the preparatory period. At the beginning of the preparatory period, the group consisted of 3 athletes qualified for the title of Master of Sports of Ukraine, 9 athletes - Candidate Master of Sports, 6 athletes - first-class sport qualification and 2 athletes - second-class sport qualification.

Mathematical and spectral methods of heart rate variability (HRV) analysis were used to assess the state of the neurohumoral heart regulation mechanisms, activity of segmental and suprasegmental levels of the autonomous nervous system (ANS) [4]. 5-minute short ECG recordings were used for the HRV analysis according to the International Standard [16].

The analysis of the ANS was carried out using a stress-index, an integral indicator of HRV. Based on the recommendation of R. M. Bayevskiy [1], vagotonia is assumed if the stress-index is less than 50 relative units (r. u.), normotonia - if the stress-index is within the range of 51-199 r. u. and sympathicotonia - if the stress-index is more than 200 r. u.

Central hemodynamic parameters were examined by an automated tetrapolar rheography method according to W. Kubiček et al. (1970) Y. T. Pushkar et al. modified (1970) [12]. Stroke volume (SV) and cardiac output (CO), stroke and cardiac indices $(\mathrm{SI}, \mathrm{Cl})$, systemic vascular resistance (SVR) and systemic vascular resistance index (SVRI) were calculated.

Physical working capacity was measured according to a common technique on a cycling ergometer using a submaximal $P W_{170}$ test [14] and calculating the relative value of physical working capacity, i.e. $\mathrm{PWC}_{170 / \mathrm{kg}}$. The functional state index (FSI) was calculated according to the formula that we had proposed and patented [11].

The study results were analyzed statistically with Statistica for Windows 13 (StatSoft Inc., № JPZ804I382130ARCN10-J). All the data were presented as the sample mean $(M) \pm$ the standard error $(m)$. The significance of mean differences was analyzed by a two-tailed $t$-test for dependent variables. The difference between two subsets of data was considered statistically significant at a value of $P$ less than 0.05 . Pair-wise Pearson's correlation was used to analyze an association between HRV, central hemodynamic and physical working capacity indices.

\section{Results}

Most researchers think that analysis of resting heart rhythm variability is the best objective, informative and sensitive method to assess functional state and physical preparation in sports. A comparison between studied HRV indicators showed no significant differences in most of them. A favorable upward trend in mode (Mo) from $0.890 \pm 0.035 \mathrm{~s}$ to $0.938 \pm 0.036 \mathrm{~s}(P=0.153)$ and range of variability $(D)$ from $0.523 \pm 0.006 \mathrm{~s}$ to $0.599 \pm 0.119 \mathrm{~s}(\mathrm{P}=0.616)$ as well as a downward trend in AMo/D from $105.67 \pm 29.21 \% / \mathrm{s}$ to $78.16 \pm 10.93 \% / \mathrm{s}(P=0.381)$ and in the stress-index from $60.09 \pm 15.72$ r.u. to $43.73 \pm 6.73$ r.u. $(P=0.358)$ was observed in time-domain HRV indicators in the competitive period. The resulting shifts indicated favorable changes in autonomous balance with a trend towards predominantly parasympathetic effects of the ANS. The results obtained were confirmed by a downward trend in mean heart rate $(\mathrm{HR})$ value from $60.05 \pm 2.63 \mathrm{bpm}$ to $57.95 \pm 2.10 \mathrm{bpm}$ $(P=0.250)$.

It is known that the autonomous rhythm index (ARI) allows ascertaining the autonomous balance and the higher its activity, the less the ARI; the more the autonomous balance is shifted towards the parasympathetic arm of the ANS predominance, the higher the adaptive reserve including sports one. In the preparatory period, the autonomous balance index had a mean value of $3.104 \pm 0.494$ $1 / \mathrm{s}^{2}$, and in the competitive period $-2.459 \pm 0.2481 / \mathrm{s}^{2}$ $(P=0.295)$, respectively.

The initial distribution of athletes according to the value of autonomous tone based on the classification proposed by R. M. Bayevskiy [1] in the preparatory period was as followis: $75.0 \% / 20.0 \% / 5.0 \%$, vagotonic, normotonic and sympathotonic individuals, respectively, statistically significantly indicating the prevalence of athletes with vagotonia over normotonic individuals $(P=0.0005)$. In the competitive period, this ratio was $60.0 \% / 40.0 \% / 0 \%$. It should be noted that there were no significant differences between vagotonic and eutonic individuals $(P=0.206)$ among the examined swimmers, at the same time, there were not sympathotonic individuals.

A decreasing trend in the central hemodynamic parameters was in the cardiac index from $2.954 \pm$ $0.126 \mathrm{I} \cdot \mathrm{min}^{-1} \cdot \mathrm{m}^{-2}$ to $2.862 \pm 0.088 \mathrm{I} \cdot \mathrm{min}^{-1} \cdot \mathrm{m}^{-2}(\mathrm{P}=0.510)$, while these values matched to the eukinetic circulatory type (CT) during both training periods. However, the percentage of CT was $45.0 \% / 45.0 \% / 10.0 \%$ in the preparatory period, and $45.0 \% / 55.0 \% / 0 \%$-in the competitive period, hypokinetic, eukinetic and hyperkinetic CT, respectively. Despite an increase of two swimmers (10\%) in the number of athletes with eukinetic CT, we believe that there were beneficial developments in the competitive period since the absence of athletes with unfavorable hyperkinetic CT.

The relative values of physical working capacity and functional state index (FSI) significantly changed. The mean value of $P C_{170 / k g}$ was $15.54 \pm 0.66 \mathrm{kgm} \cdot \mathrm{min}^{-1} \cdot \mathrm{kg}^{-1}$ in the preparatory period, and increased by $16.41 \%$ $(P=0.0001)$ and totaling $18.09 \pm 0.53 \mathrm{kgm} \cdot \mathrm{min}^{-1} \cdot \mathrm{kg}^{-1}$ in the competitive period.

The FSI increased significantly by $25.08 \%$ from $5.558 \pm 0.322$ r. u. to $6.952 \pm 0.272$ r. u. $(P=0.00001)$. Based on our classification, low FSI score was in the preparatory period, and it increased to below the average in the competitive period. The individually assessed functional state in the preparatory period was as follows: low score in 12 swimmers $(60.0 \%)$, lower the average score in 7 (35.0\%), medium score in 1 swimmer (5.0\%). In the competitive period, the FSI was low in 7 (35.0\%), lower the average score in $10(50.0 \%)$, and medium in 3 swimmers $(15.0 \%)$. Thus, in the competitive period, the number of swimmers with medium score increased by $10.0 \%$, with below the average - by $15.0 \%$, and the number of swimmers with low score decreased by $25.0 \%$.

The correlation analysis during the preparatory period showed a significant positive correlation between Mo and 
$\mathrm{PWC}_{170 / \mathrm{kg}}(r=0.46, \mathrm{P}=0.040), \mathrm{ARI}$ and $\mathrm{Cl}(r=0.50$, $P=0.026)$, indicator of the adequacy of regulation processes (IARP) and $\mathrm{Cl}(r=0.53, \mathrm{P}=0.017)$, stress-index and SI $(r=0.52, P=0.019)$ and negative - between Mo and $\mathrm{Cl}(r=-0.56, P=0.009)$. Mo is known to be an indicator showing a probable level of cardiovascular functioning and the higher it is, the higher parasympathetic effect of the ANS and, in our case, the higher $\mathrm{PWC}_{170 / \mathrm{kg}}$

The ARI made it possible to assess autonomous balance and effect of its reduction on the $\mathrm{Cl}$ valuing the premise of a shift towards the dominance of parasympathetic regulation and a decrease in $\mathrm{Cl}$. A decrease in the IARP values also indicated the prevalence of parasympathetic effects and a decrease in $\mathrm{Cl}$. The decrease in the stress-index unidirectionally contributed to the decrease in SI, and finally, a reliable increase in the Mo advantageously led to a decrease in $\mathrm{SI}$, resulting in its economy when the values corresponding to the hypokinetic CT were reached.

In the competitive period, the general tendency of correlation interaction was remained, as evidenced by revealed positive relationships between Mo and FSI $(r=0.53$, $P=0.017), A R I$ and $S I(r=0.51, P=0.020)$.

The dynamics of increasing athletic performance in a one-year training cycle was quite interesting. In the competitive period, four athletes CMS qualified for the title of MS, two first-class swimmers - for the CMS title, and two second-class swimmers - for the first-class athletes. Thus, there were seven MS of Ukraine, seven swimmers CMS and six first-class swimmers in the examined group.

\section{Discussion}

As shown above, few studies were carried out on dynamic observations of the functional state among athletes. Dynamic examinations of 15 futsal players showed a significant improvement in pedagogical tests and some indices of HRV in the competitive period as compared to those during short 3-week preparatory period indicating the prevalence of parasympathetic regulation among examined athletes [14]. The authors suppose that monitoring the results of these tests and HRV indicators can help to assess a level of adaptation in athletes and/or to detect signs of deadaptation earlier. Examination of HRV carried out during pre-competition and competition periods among 11 volleyball players showed significant differences in spectral and time-domain HRV parameters [15]. The significant increase in very low frequency (VLF) (\%) in the competitive period could be due to a state of increased psychophysiological arousal. The authors suggest that the resting bradycardia identified by the time-domain HRV parameters analysis may be the result of internal changes in the sinoatrial node possibly reflecting an impact of long-term training on the cardiac conduction system. The high level of physical activity in volleyball players during the studied periods can certainly contribute to the vagal tone reduction and a shift of the ANS balance towards the sympathetic arm, which might reflect their decline.

Dynamic observations [13] of the 9 handball players conducted at the end of the competitive period and at the beginning of the preparatory period which was preceded by the 4-week total endurance training for the next sports season showed a significant increase in $\mathrm{PWC}_{170 / \mathrm{kg}}$ from $2.73 \pm 0.51 \mathrm{~W} / \mathrm{kg}$ to $3.06 \pm 0.42 \mathrm{~W} / \mathrm{kg}(P<0.01)$.
Studies conducted by O. N. Kudrja [3] showed that 22 handball players qualified from first-class athletes to MS experienced a significant increase in $\mathrm{PWC}_{170 \mathrm{~kg}}$ from $18.10 \pm 0.77$ to $21.00 \pm 0.67 \mathrm{kgm} \cdot \mathrm{min}^{-1} \cdot \mathrm{kg}^{-1}$, heart rate reduction from $65.0 \pm 2.09$ to $55.1 \pm 1.96$ and stress-index decrease from $64.01 \pm 6.98$ to $35.94 \pm 5.26$ r. u. $(P<0.05)$ between the beginning of the preparatory period and the beginning of the competitive period.

Thus, in the competitive period, in line with improvements in the pedagogical tests among team-sport athletes, there were significant favorable developments in ANS and physical working capacity. The data obtained by us in swimmers also has shown a positive dynamics of HRV and PWC and, most importantly, athletic performance has been reflected in achieving the normative of MS of Ukraine, CMS and first-class athletes by some swimmers. It is also worthwhile noting that in team sports, some players might have had reduced functional state and overexertion, especially on the cardiovascular system and ANS, that was dwarfed by a high level of functional state in other team members who ensured the athletic team achievement. For this reason, athletes engaged in individual sports were at a substantial disadvantage as a decrease in functional state showed a decrease in athletic performance.

\section{Conclusions}

1. There was the substantial prevalence of parasympathetic tone of the ANS with the upward trend in the number of athletes with vagotonia, absence of athletes with hyperkinetic $\mathrm{CT}$, the significant increase in physical working capacity by $16.41 \%$ and FSI by $25.08 \%$ among short-distance swimmers in the competitive period as compared to the preparatory one.

2. Correlation analysis carried out in the preparatory period of the training process showed favorable relationships that were reflected in the increased physical working capacity of swimmers as Mo values were increased, decreased $\mathrm{Cl}$ values as ARI and IARP were decreased, increased Mo and decreased SI as the stress-index was decreased.

3 . In the competitive period, these relationships remained, as well as the increased athletic performance since four swimmers qualified for the title of Master of Sports of Ukraine, two first-class swimmers qualified for Candidate Master of Sports, and two second-class swimmers - for first-class athletes.

Study limitations. Statistically insignificant changes in some studied indicators in our work are explained by the low statistical power of the study as well as the heterogeneity of the group by the level of sports qualification. The latter points to the need for a stronger focus on the development of certain physical performance for further progression in the sport chosen at the training process stages, rather than on an enforcing the sport achievements, for athletes of mass categories (first- and second-class).

The prospects for further research are to study the effect of training loads from the preparatory to the competitive period of the training process on the HRV indicators, central hemodynamics and physical working capacity among athletes in other sports including sex differences. 
Conflict of interest: authors have no conflict of interest to declare. Конфлікт інтересів: віАсутній.

Надійшка Ао реАакції / Received: 03.11.2020

Після Аоопрацювання / Revised: 18.01.2021

Прийнято Ао Аруку / Accepted: 21.01.2021

Information about authors:

Mykhaliuk Ye. L., MD, PhD, DSc, Professor, Head of

the Department of Physical Rehabilitation, Sports Medicine,

Physical Education and Health, Zaporizhzhia State Medical

University, Ukraine.

ORCID ID: 0000-0003-3607-7619

Syvolap V. V., MD, PhD, DSc, Professor, Head of the Department of Propedeutic of Internal Medicine, Radiation Diagnostic and Radiation Therapy, Zaporizhzhia State Medical University, Ukraine. ORCID ID: 0000-0001-9865-4325

Horokhovskyi Ye. Yu., PhD, Associate Professor of the Department of General and Applied Ecology and Zoology, Zaporizhzhia National University, Ukraine.

Potapenko M. S., MD, PhD, Assistant of the Department of Anesthesiology and Intensive Care, Zaporizhzhia State Medica University, Ukraine.

\section{Відомості про авторів:}

Михалюк Є. А., А-р меА. наук, професор, зав. каф. фізично реабімітації, спортивної медицини, фізичного виховання і зАоров'я, Запорізький Аержавний медичний університет, україна.

Сиволап В. В., А-р меА. наук, професор, зав. каф. пропедевтики внутрішньої медицини, променевої Аіагностики та променевої терапії, Запорізький державний медичний університет, Україна.

Гороховський Є. Ю., канд. біол. наук, Аоцент каф. загально та прикладної екології і зоології, Запорізький національний університет, Україна.

Потапенко М. С., канА. меА. наук, асистент каф. анестезіологіі та інтенсивної терапії, Запорізький Аержавний меАичний університет, Україна.

\section{Сведения об авторах:}

Миха^юк Е. ^., А-р меА. наук, профессор, зав. каф. физической реабилитации, спортивной медицины, физического воспитания и зАоровья, Запорожский государственный меАицинский университет, Украина.

Сыволап В. В., А-р меА. наук, профессор,

зав. каф. пропедевтики внутренней медицины, лучевой Аиагностики и мучевой терапии, Запорожский государственный медицинский университет, Украина.

Гороховский Е. Ю., канА. биол. наук, Аоцент каф. общей и приклаАной экологии и зоологии, Запорожский национальный университет, Украина.

Потапенко М. С., канА. меА. наук, ассистент

каф. анестезиологии и интенсивной терапии, Запорожский

государственный медицинский университет, Украина.

\section{References}

[1] Baevskii, R. M., \& Berseneva, A. P. (1997). Otsenka adaptatsionnykh vozmozhnostei organizma i risk razvitiya zabolevanii [Assessment of adaptation capabilities of the organism and a risk of disease development]. Meditsina. [in Russian]

[2] Karpman, V. L. (1980). Funkcional'naya diagnostika v sportivnoj medicine [Functional diagnostics in sports medicine]. Klinicheskaya medicina, (6), 3-7. [in Russian].

[3] Kudrya, O. N. (2014). Otsenka funktsional'nogo sostoyaniya i fizicheskoi podgotovlennosti sportsmenov po pokazatelyam variabel'nosti serdechnogo ritma [Evaluation of functional state and physical preparedness of athletes on indicators of the heart rate variability]. Vestnik Novosibirskogo gosudarstvennogo pedagogicheskogo universiteta, (1), 185-196. [in Russian].

[4] Mikhailov, V. M. (2002). Variabel'nost' ritma serdtsa: opyt prakticheskogo primeneniya metoda [Heart rate variability: the experience of practical implementation of the method] (2nd ed.). Ivanovskaya gosudarstvennaya meditsinskaya akademiya. [in Russian].
[5] Mikhalyuk, E. L. (1989). Sostoyanie tsentral'noi i regionarnoi gemodinamiki u legkoatletov-metatelei v godichnom tsikle trenirovochnogo protsessa. (Avtoref. dis. ... kand. med. nauk). [Central and peripheral hemodynamic parameters in throwers in the process of an annual training cycle]. (Extended abstract of candidate's thesis). Moscow. [in Russian].

[6] Mikhalyuk, Ye. L. (2015). Osoblyvosti naukovykh doslidzhen u sportyvnil medytsyni na suchasnomu etapi [Specifics of scientific research in sports medicine at the present stage]. Zaporozhye medical journal, (5) 82-84. https://doi.org/10.14739/2310-1210.2015.5.53821 [in Ukrainian].

[7] Mikhalyuk, Ye. L., Didenko, M. V., \& Malakhova, S. N. (2016). Vplyv tsilorichnykh trenuvan na stan sertsevo-sudynnoi, avtonomnoi nervovoi systemy ta fizychnoi pratsezdatnosti u zhinok-bihuniv na 400 metriv [Influence of yearlong training on the state of cardiovascular autonomic nervous system and physical performance in female 400 meters runners]. Pathologia, (1), 54-60. https://doi.org/10.14739/23101237.2016.1.71189 [in Ukrainian].

[8] Mikhaluk, E. L., Didenko, M. V., \& Malakhova, S. N. (2016). Zminy intehralnykh pokaznykiv funktsionalnoho stanu lehkoatletok-sprynteriv u richnomu tsykli trenuvalnoho protsesu [Change in integral functional status of female athletes-sprinters in the annual cycle of training process]. Bukovynskyi medychnyi visnyk, 20(2), 91-95 [in Ukrainian].

[9] Mikhalyuk, Ye. L., Malakhova, S. N \& Didenko, M. V. (2016). Dynamichni sposterezhennia za vehetatyvnym zabezpechenniam tsentralnoi hemodynamiky ta fizychnoi pratsezdatnosti bihuniv na dystantsii 400 metriv [Dynamic observation of vegetative support of central hemodynamics and physical performance in 400-m runners]. Zaporozhye medical journal, (1), 29-34. https://doi.org/10.14739/23101210.2016.1.64052 [in Ukrainian].

[10] Mikhalyuk, Ye. L., Malakhova, S. N., \& Didenko, M. V. (2016). Shchorichni sposterezhennia za funktsionalnym stanom lehkoatletiv-sprynteriv [Yearlong observation of functional status of athletes-sprinters] Zhurnal klinichnykh ta eksperymentalnykh medychnykh doslidzhen, 4(2), 201-208. [in Ukrainian].

[11] Mykhaliuk, Ye. L., Syvolap, V. V., \& Tkalich, I. V. (2008). Sposib otsinky funktsionalnoho stanu orhanizmu osib, shcho zaimaiutsia fizychnoiu kulturoiu ta sportom [Method for assessing functional state of body in persons practicing sports] (Ukraine. Patent No. 36013). Ukraina. Derzhavna sluzhba intelektualnoi vlasnosti Ukrainy. https://base. uipv.org/searchINV/search.php?action=viewdetails\&IdClaim=124703 [in Ukrainian].

[12] Karpman, V. L., Belotserkovskii, Z. B., \& Gudkov, I. A. (1988). Testirovanie $v$ sportivnoi meditsine [Testing in sports medicine]. Fizkul'tura $\mathrm{i}$ sport. [in Russian]

[13] Boraczyński, T., \& Urniaż, J. (2008). Changes in Aerobic and Anaerobic Power Indices in Elite Handball Players Following a 4-Week General Fitness Mesocycle. Journal of Human Kinetics, 19(1), 131-140. https:// doi.org/10.2478/v10078-008-0010-1

[14] Oliveira, R. S., Leicht, A. S., Bishop, D., Barbero-Álvarez, J. C. \& Nakamura, F. Y. (2013). Seasonal Changes in Physical Performance and Heart Rate Variability in High Level Futsal Players. International Journal of Sports Medicine, 34(5), 424-430. https://doi. org/10.1055/s-0032-1323720

[15] Podstawski, R., Boraczyński, M., Nowosielska-Swadźba, D., \& Zwolińska, D. (2014). Heart rate variability during pre-competition and competition periods in volleyball players. Biomedical Human Kinetics, 6(1), 19-26. https://doi.org/10.2478/bhk-2014-0004

[16] (1996). Heart rate variability: standards of measurement, physiological interpretation and clinical use. Task Force of the European Society of Cardiology and the North American Society of Pacing and Electrophysiology. Circulation, 93(5), 1043-1065. https://doi.org/10.1161/01. CIR.93.5.1043 